\title{
Gamna-Gandy nodules of the spleen and asplenism in SLE: a novel association?
}

\author{
Annefleur J Petri, ${ }^{1}$ Maarten Limper, ${ }^{2}$ Anya Milne, ${ }^{3}$ Lenneke E M Haas ${ }^{4}$
}

${ }^{1}$ Anesthesiology, VU Medisch Centrum, Amsterdam, The Netherlands

${ }^{2}$ Internal Medicine and Dermatology, Rheumatology and Clinical Immunology, UMC Utrecht, Utrecht, The Netherlands

${ }^{3}$ Pathology, Diakonessenhuis Utrecht, Utrecht, The Netherlands

${ }^{4}$ Intensive Care,

Diakonessenhuis Utrecht, Utrecht, The Netherlands

\section{Correspondence to Lenneke E M Haas, |vlelyveld@diakhuis.n|}

Accepted 7 July 2017

\section{DESCRIPTION}

We present a case of a 53-year-old woman who presented to the emergency room with acute abdominal pain, fever and haemodynamic and respiratory instability and was admitted to the intensive care unit with fulminant septic shock with multiorgan failure. CT imaging of the abdomen showed no gross abnormalities, initial laboratory results are presented in table 1.

Despite adequate resuscitation, broad-spectrum antibiotics and supportive care, following the International Guidelines of the Surviving Sepsis Campaign, she died within a couple of hours. The patient had a history of systemic lupus erythematosus (SLE) with arthralgia, positive antinuclear antibodies and persistently high anti-DNA antibodies, but without active disease and no immunosuppressive medication since years.

Leucocyte typing of the initial peripheral blood smear showed Howell-Jolly bodies and diplococci, indicating massive bacterial load and functional asplenism. Functional asplenism or hyposplenism is present in up to $5 \%$ of patients with SLE with or without disease activity before. ${ }^{1}$ No thrombocytosis or antiphospholipid antibodies-that are suggested as clues to autosplenectomy-were found in our patient. $^{2}$

Postmortem blood cultures became positive for Streptococcus pneumonia. Pathology revealed perivascular infiltrates in the liver and GamnaGandy bodies (GGB) in a remarkably small spleen (figure 1).

The patient did not take medication or drugs that could explain this image of the liver. GGB or haemosiderotic nodules are foci of haemosiderin deposition resulting from intrasplenic haemorrhage (figure 2 and figure 3). Portal hypertension

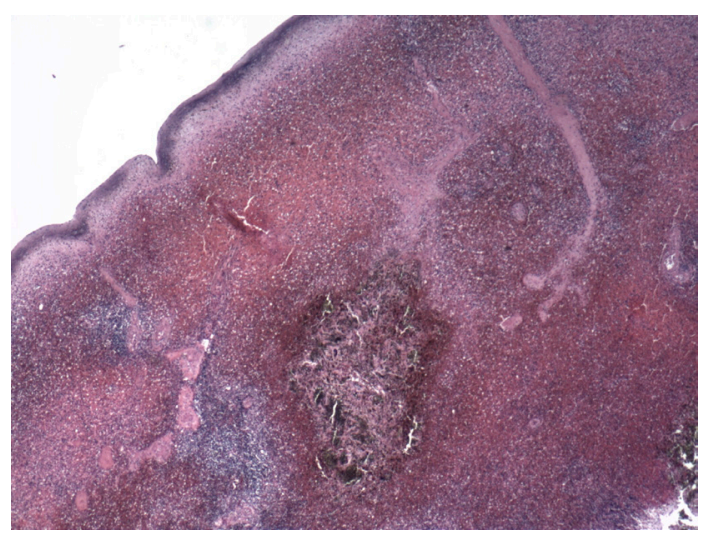

Figure 1 Microscopy of the spleen (HE $\times 25)$, revealing Gamna-Gandy nodules (centre).

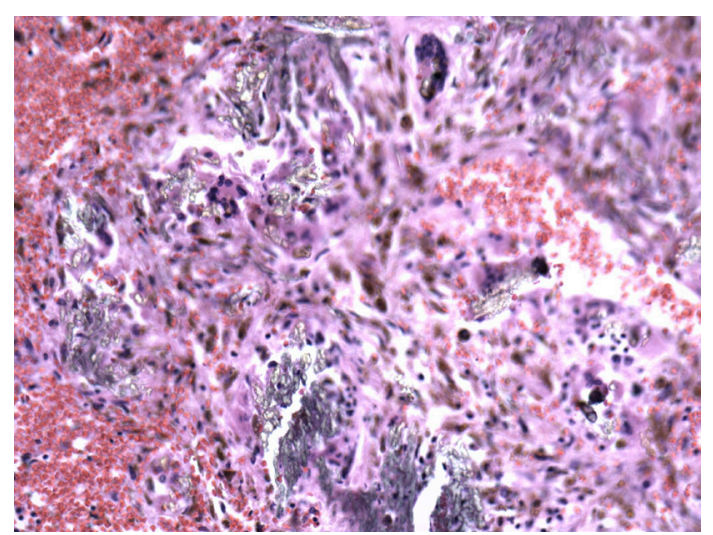

Figure 2 High-power view (HE $\times 200)$ of the GamnaGandy bodies. These rust-coloured foci contained fibrous tissue with haemosiderin deposits, and probably form due to scarring at sites of small perivascular haemorrhages.

is considered the primary cause of GGBs and their appearance is associated with sickle-cell anaemia, hereditary haemochromatosis, haemolytic anaemia, acquired haemosiderosis, paroxysmal nocturnal haemoglobinuria, portal or splenic vein thrombosis, leukaemia, lymphoma and repeated blood transfusion. ${ }^{3}$ However, these conditions known to be associated with GGB were absent in our patient.

Although the pathophysiological processes leading to hyposplenism in SLE remain largely unknown, it has been proposed that this is a result of silent infarction due to hyposplenism. ${ }^{4}$ As a consequence of inflammatory microvessel damage, splenic haemosiderin depositions may occur and remain visible, also after the resolution of vasculitis. Furthermore, despite the absence of antiphospholipid antibodies in this patient, splenic

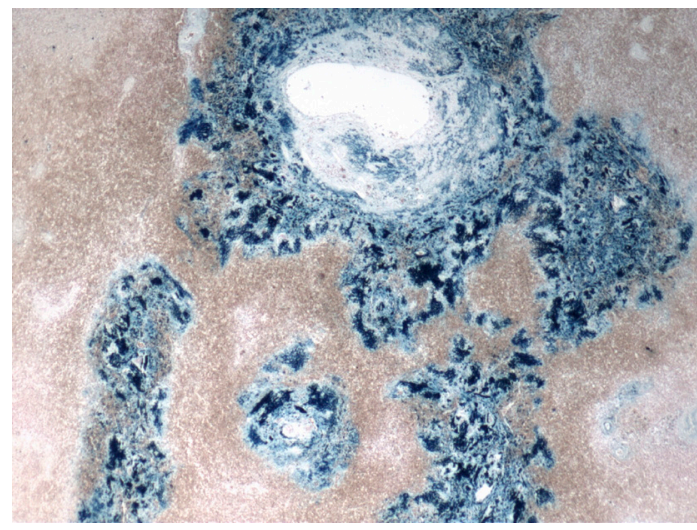

Figure 3 Prussian blue stain showing iron deposition (blue) in the Gamna-Gandy bodies. 


\begin{tabular}{|c|c|c|c|}
\hline Parameter & Value & Reference value & Unit \\
\hline CRP & 96 & $<10$ & $\mathrm{mg} / \mathrm{L}$ \\
\hline ESR & 7 & $<20$ & $\mathrm{~mm} /$ hour \\
\hline $\mathrm{Hb}$ & 8.0 & $7.0-9.2$ & $\mathrm{mmol} / \mathrm{L}$ \\
\hline $\mathrm{Ht}$ & 0.40 & $0.32-0.44$ & $\mathrm{~L} / \mathrm{L}$ \\
\hline MCV & 95 & $82-89$ & $\mathrm{fL}$ \\
\hline WBC & 6.5 & $3.0-10.0$ & $10^{9} / \mathrm{L}$ \\
\hline Platelet count & 37 & $150-350$ & $10^{9} / \mathrm{L}$ \\
\hline \multicolumn{4}{|c|}{ NB platelet count 10 days earlier: $318 \times 10^{9} / \mathrm{L}$} \\
\hline APTT & 93 & $22-34$ & $\mathrm{sec}$ \\
\hline PT & 30.5 & $9.5-12.5$ & $\mathrm{sec}$ \\
\hline Creatinine & 411 & $44-80$ & $\mu \mathrm{mol} / \mathrm{L}$ \\
\hline Urea & 17 & $2.5-6.4$ & $\mathrm{mmol} / \mathrm{L}$ \\
\hline Sodium & 140 & $135-145$ & $\mathrm{mmol} / \mathrm{L}$ \\
\hline Potassium & 4.0 & $3.5-5.0$ & $\mathrm{mmol} / \mathrm{L}$ \\
\hline Chloride & 95 & $98-108$ & $\mathrm{mmol} / \mathrm{L}$ \\
\hline Glucose & 0.6 & $3.0-7.0$ & $\mathrm{mmol} / \mathrm{L}$ \\
\hline Lactate & 14.6 & $0.5-2.2$ & $\mathrm{mmol} / \mathrm{L}$ \\
\hline AP & 118 & $<98$ & $\mathrm{U} / \mathrm{L}$ \\
\hline Gamma-GT & 78 & $<38$ & $\mathrm{U} / \mathrm{L}$ \\
\hline ALAT & 124 & $<34$ & $\mathrm{U} / \mathrm{L}$ \\
\hline ASAT & 329 & $<31$ & $\mathrm{U} / \mathrm{L}$ \\
\hline LDH & 1748 & $<247$ & $\mathrm{U} / \mathrm{L}$ \\
\hline Amylase & 97 & $<107$ & $\mathrm{U} / \mathrm{L}$ \\
\hline CK & 1269 & $<145$ & $\mathrm{U} / \mathrm{L}$ \\
\hline \multicolumn{4}{|c|}{ Arterial blood gas } \\
\hline pH & 7.24 & $7.35-7.45$ & \\
\hline $\mathrm{pCO}_{2}$ & 2.6 & $4.6-6.4$ & $\mathrm{kPa}$ \\
\hline $\mathrm{pO}_{2}$ & 17.2 & $10.0-13.3$ & $\mathrm{kPa}$ \\
\hline $\mathrm{HCO}_{3}$ & 8.2 & $22.0-29.0$ & $\mathrm{mmol} / \mathrm{L}$ \\
\hline BE & -17.1 & $-3.0-3.0$ & $\mathrm{mmol} / \mathrm{L}$ \\
\hline $\mathrm{sO}_{2}$ & 98 & $95-98$ & $\%$ \\
\hline
\end{tabular}

ALAT, alanine aminotransferase; AP, alkaline phosphatase; APPT, activated partial thromboplastin time; $\mathrm{ASAT}$, aspartate aminotransferase; $\mathrm{BE}$, base excess; $\mathrm{CK}$, creatine kinase; CRP, C reactive protein; Gamma-GT, gamma-glutamyl transferase; $\mathrm{Hb}$, haemoglobin; $\mathrm{Ht}$, haematocrit; $\mathrm{LDH}$, lactate dehydrogenase; MCV, mean corpuscular volume; $\mathrm{pCO}_{2}$, partial pressure of carbon dioxide; $\mathrm{pO}_{2}$, partial pressure of oxygen; $\mathrm{SO}_{2}$, oxygen saturation; $\mathrm{PT}$, prothrombin time; $\mathrm{WBC}$, white blood cell.

microangiopathy and microthrombosis associated with SLE may have contributed to 'leaky' splenic microvasculature, resulting in GGBs and partial autosplenectomy as described above.
In conclusion, this case once again illustrates the association of SLE with asplenism and the fulminant course of pneumococcal sepsis in those patients, ${ }^{5}$ despite disease inactivity for years. Moreover, GGB were found, which could not be related to known associated diseases. As far as we know, this is the first case describing GGB in a patient with SLE and functional asplenism.

\section{Learning points}

- Functional asplenism or hyposplenism is present in a small but significant part of patients with systemic lupus erythematosus (SLE), regardless of disease activity and use of immunosuppressive medication. Diagnostic clues indicating a susceptibility to splenic hypofunction or dysfunction remain uncertain, making it impossible to predict which patients will develop asplenism.

- Taking into account the fulminant course of pneumococcal infection in patients with SLE and asplenism, prophylactic vaccination should be considered in every patient with $\mathrm{SLE}^{4}{ }^{5}$

- This is the first case that describes GGB in a patient with SLE and functional asplenism.

Contributors LEMH and AJP: contributed equally to the writing of this manuscript and were personally involved with the case. AM: provided the pathology images and wrote the figure captions. ML: shared his expertise on the subject in trying to explain the findings in this particular setting. AM and ML: reviewed the draft text.

Competing interests None declared.

Patient consent Obtained.

Provenance and peer review Not commissioned; externally peer reviewed. (c) BMJ Publishing Group Ltd (unless otherwise stated in the text of the article) 2017. All rights reserved. No commercial use is permitted unless otherwise expressly granted.

\section{REFERENCES}

1 Fishman D, Isenberg DA. Splenic involvement in rheumatic diseases. Semin Arthritis Rheum 1997;27:141-55.

2 Castellino G, Govoni M, Prandini N, et al. Thrombocytosis in systemic lupus erythematosus: a possible clue to autosplenectomy? I Rheumatol 2007;34:1497-501.

3 Vanhoenacker FM, Op de Beeck B, De Schepper AM, et al. Vascular disease of the spleen. Semin Ultrasound CT MRI 2007;28:35-51.

4 Santilli D, Govoni M, Prandini N, et al. Autosplenectomy and antiphospholipid antibodies in systemic lupus erythematosus: a pathogenetic relationship? Semin Arthritis Rheum 2003;33:125-33

5 Mackenzie AR, Laing RB, MacDonald AG, et al. Pneumococcal septicaemia in a patient with systemic lupus erythematosus. Ann Rheum Dis 1997;56:403-4.

Copyright 2017 BMJ Publishing Group. All rights reserved. For permission to reuse any of this content visit http://group.bmj.com/group/rights-licensing/permissions.

BMJ Case Report Fellows may re-use this article for personal use and teaching without any further permission.

Become a Fellow of BMJ Case Reports today and you can:

- Submit as many cases as you like

- Enjoy fast sympathetic peer review and rapid publication of accepted articles

- Access all the published articles

- Re-use any of the published material for personal use and teaching without further permission

For information on Institutional Fellowships contact consortiasales@bmjgroup.com

Visit casereports.bmj.com for more articles like this and to become a Fellow 